\title{
Constituent phases and mechanical properties of iron oxide-additioned phosphoaluminate cement
}

\author{
Shuai Yang, Shoude Wang $\bowtie$, Chenchen Gong, Lingchao Lu, Xin Cheng \\ Shandong Provincial Laboratory for the Preparation and Measurement of Building Materials, University of Jinan (Jinan, China) \\ \yangshuai23@163.com, personand98@163.com
}

Received 29 March 2014

Accepted 3 December 2014

Available on line 16 April 2015

\begin{abstract}
Iron oxide was added to phosphoaluminate clinker and its effects on cement constituents were determined using XRD, DSC, SEM-EDS and conduction calorimetry analysis. The variations in compressive strength were also studied. The results showed that in moderate amounts, iron oxide acts as a mineraliser during clinker sintering, furthering the conversion of $\mathrm{CA}_{1-\mathrm{Y}}\left(\mathrm{P}_{\mathrm{Y}}\right)$ to LHss at a lower temperature than normally required for that reaction. The main constituents of iron oxide-rich phosphoaluminate clinker included LHss, $\mathrm{CA}_{1-\mathrm{Y}}\left(\mathrm{P}_{\mathrm{Y}}\right)$, $\mathrm{CP}_{1-\mathrm{Z}}\left(\mathrm{A}_{\mathrm{Z}}\right)$ and ferrite. The EDS findings showed that the composition of the ferrite phase was nonuniform. The conclusion drawn was that by modifying the dose of $\mathrm{Fe}_{2} \mathrm{O}_{3}$, the composition of phosphoaluminate cement can be controlled to produce clinker and cement compliant with different mechanical strength requirements. The conduction calorimetry findings were consistent with those results.
\end{abstract}

KEYWORDS: Phosphoaluminate cement; Ferrite phase; Phase constituents; Mechanical properties

Citation/Citar como: Shuai Yang, Shoude Wang, Chenchen Gong, Lingchao Lu, Xin Cheng. (2015) Constituent phases and mechanical properties of iron oxide-additioned phosphoaluminate cement. Mater. Construcc. 65 [318], e052 http://dx.doi.org/10.3989/mc.2015.02214.

RESUMEN: Fases constituyentes y propiedades mecánicas de un cemento de fosfoaluminato con adición de óxido de hierro. Este trabajo estudia, mediante DRX DSC, SEM-EDS y calorimetría de conducción, el efecto de la adición de óxido de hierro a un clinker de fosfoaluminato, así como las variaciones sufridas en su resistencia a compresión. Los resultados mostraron que en cantidades moderadas, el óxido de hierro actúa como mineralizador durante la sinterización del clinker, promoviendo la conversión de $\mathrm{CA}_{1-\mathrm{Y}}\left(\mathrm{P}_{\mathrm{Y}}\right)$ a LHss a una temperatura más baja de la normalmente requerida. Los componentes principales del clínker de fosfoaluminato con óxido de hierrop son LHss, $\mathrm{CA}_{1-\mathrm{Y}}\left(\mathrm{P}_{\mathrm{Y}}\right), \mathrm{CP}_{1-\mathrm{Z}}\left(\mathrm{A}_{\mathrm{Z}}\right)$ y fase ferritica. Los resultados de EDS mostraron que la composición de esta fase ferrítica no era uniforme. DE este estudio se ha podido concluir que variando la dosificación del $\mathrm{Fe}_{2} \mathrm{O}_{3}$, se puede controlar la composición del fosfoaluminato para producir clinker y cemento compatibles con diferentes requisitos de resistencia mecánica. Los resultados de calorimetría de conducción fueron consistentes con los resultados.

PALABRAS CLAVE: Cemento de fosfoaluminato; Fase ferrítica; Constituyentes de fase; Comportamiento mecánico

Copyright: (C) 2015 CSIC. This is an open-access article distributed under the terms of the Creative Commons Attribution-Non Commercial (by-nc) Spain 3.0 License.

\section{INTRODUCTION}

High aluminate cement is a special binder whose quick hardening and chemical resistance make it suitable for repairing highways, airport runways and similar. Its hydration products include $\mathrm{CAH}_{10}$, $\mathrm{C}_{2} \mathrm{AH}_{8}, \mathrm{C}_{3} \mathrm{AH}_{6}$ and $\mathrm{AH}_{3}$. At ambient temperature, $\mathrm{CAH}_{10}$ and $\mathrm{C}_{2} \mathrm{AH}_{8}$, known to be metastable, convert to $\mathrm{C}_{3} \mathrm{AH}_{6}$ and $\mathrm{AH}_{3}$, lowering mechanical strength (1-3). A number of methods are in place 
to attenuate or prevent that conversion (4-6). Shiqun and Jiashan et al. (7-10) found that a new phase containing $\mathrm{P}$ and $\mathrm{Si}$ and named LHss forms in the $\mathrm{CaO}-\mathrm{Al}_{2} \mathrm{O}_{3}-\mathrm{P}_{2} \mathrm{O}_{5}-\mathrm{SiO}_{2}$ quaternary system. Later research showed that the hydration products of this new phase were stable at later curing ages, an indication that including $\mathrm{P}$ and $\mathrm{Si}$ in solid solution could effectively inhibit the conversion from $\mathrm{CAH}_{10}$ and $\mathrm{C}_{2} \mathrm{AH}_{8}$ to $\mathrm{C}_{3} \mathrm{AH}_{6}$ and $\mathrm{AH}_{3}$. Further to electron probe microanalysis findings, the chemical composition of new phase LHss is $\mathrm{CaO} \cdot(1-\mathrm{X}-\mathrm{Y}) \mathrm{Al}_{2} \mathrm{O}_{3} \cdot \mathrm{XSiO}_{2} \cdot \mathrm{YP}_{2} \mathrm{O}_{5}, \quad \mathrm{X}=0.146-0.206$, $\mathrm{Y}=0.048-0.081$ (7). This solid calcium phosphoaluminate solution deriving from monocalcium aluminate was subsequently used as the main mineral phase in the invention of a phosphoaluminate cement (PALC) with excellent mechanical properties.

In addition to the LHss, this new cement contains modified calcium phosphate $\left(\mathrm{CP}_{1-\mathrm{Z}}\left(\mathrm{A}_{\mathrm{Z}}\right)\right)$, modified monocalcium aluminate $\left(\mathrm{CA}_{1-\mathrm{Y}}\left(\mathrm{P}_{\mathrm{Y}}\right)\right)$ and a vitreous phase. The first two phases play important roles in later age cement strength development, while the latter two enhance early age hydration (11). PALC is characterised by high early age and increasing long-term strength. Its low alkalinity affords it long durability, its low porosity, high resistance to frost and penetration, and the absence of $\mathrm{Ca}(\mathrm{OH})_{2}$ in its hydraulic system, resistance to carbonation (12).

The drawback is that since new phase LHss forms at over $1500{ }^{\circ} \mathrm{C}$, producing this type of cement is highly energy-intensive. Earlier studies (13) explored the effect of oxides on LHss sintered at $1380{ }^{\circ} \mathrm{C}$. The addition of $\mathrm{MgO}$ to the C-S-P-A system favours CA formation, but may inhibit LHss formation. Conversely, $\mathrm{SO}_{3}$ may hasten the transformation of the main crystalline phases CA and $\mathrm{C}_{\mathrm{x}} \mathrm{P}$ to LHss. Moreover, small amounts of $\mathrm{TiO}_{2}$ further both LHss and $\mathrm{C}_{\mathrm{x}} \mathrm{P}$ formation in the C-S-P-A system (13). The optimal $\mathrm{TiO}_{2}$ content is $1.39 \mathrm{wt}^{\%} \%$, above which LHss formation is hindered. Unfortunately, however, $\mathrm{MgO}$ has an adverse effect on LHss formation, the $\mathrm{SO}_{3}$ emissions generated during sintering are environmentally harmful and $\mathrm{TiO}_{2}$ is rare.

A certain amount of ferric oxide in the raw material is known to lower the sintering temperature of portland clinker and further alite formation $(14,15)$. In alite-sulphoaluminate cement, the addition of ferric oxide enhances free lime absorption and alite formation (16). The addition of ferric oxide also lowers the sintering temperature of alite- $\mathrm{C}_{2.75} \mathrm{~B}_{1.25} \mathrm{~A}_{3} \overline{\mathrm{S}}$ cement from 1410 to $1350{ }^{\circ} \mathrm{C}$ (17) and favours the formation of sulphoaluminate clinker (18).

In light of those findings, the potential of ferric oxide to expedite LHss formation has also been studied. Wang (13) found that $4 \mathrm{wt} \%$ of the compound favours LHss formation at a temperature of $1380{ }^{\circ} \mathrm{C}$. At a proportion of $5-6 \mathrm{wt} \%$, however, it appears to lower the LHss content in the clinker. Inasmuch as the effect of high proportions of $\mathrm{Fe}_{2} \mathrm{O}_{3}$ on the formation of the constituent phases of phosphoaluminate cement has not yet been studied, the impact of proportions of over $10 \mathrm{wt} \%$ on its formation was explored here. Its effect on the constituent phases and the hydration mechanism are also discussed.

\section{EXPERIMENTAL}

\subsection{Specimen preparation}

Sinopharm Chemical Reagent Co., Ltd, 99.0\% pure laboratory reagents with a fineness of at least $74 \mu \mathrm{m}$ were used throughout: calcium carbonate $\left(\mathrm{CaCO}_{3}\right)$, calcium phosphate $\left(\mathrm{Ca}_{3}\left(\mathrm{PO}_{4}\right)_{2}\right)$, alumina $\left(\mathrm{Al}_{2} \mathrm{O}_{3}\right)$, silica $\left(\mathrm{SiO}_{2}\right)$, ferric oxide $\left(\mathrm{Fe}_{2} \mathrm{O}_{3}\right)$ and alcohol. All the materials were precisely weighed to the proportions specified in the phosphoaluminate cement design (12) and $0,10,11,12,13$ or $15 \%$ $\mathrm{Fe}_{2} \mathrm{O}_{3}$ was added to prepare specimens respectively labelled A, B, C, D, E and F. Sample G had the same composition as sample A but was sintered at a higher temperature.

The components were thoroughly blended, mixed with laboratory grade alcohol and then dried at $105^{\circ} \mathrm{C}$ for 4 hours. They were subsequently pressed into round specimens measuring $\Phi 60 \mathrm{~mm} \times 10 \mathrm{~mm}$, sintered at $1380{ }^{\circ} \mathrm{C}$ for 2 hours (ramping the temperature at a rate of $5^{\circ} \mathrm{C} /$ minute) and cooled under fast-flowing forced air. Specimen $G$ was sintered separately at $1560{ }^{\circ} \mathrm{C}$ for $2 \mathrm{~h}$, ramping at the same rate as above and fan-cooled. The seven clinkers, including specimen $\mathrm{G}$, were ground to pass the No. 200 sieve. The powder was mixed with water and the resulting paste was poured into $20 \times 20 \times 20-\mathrm{mm}^{3}$ moulds for curing at $20{ }^{\circ} \mathrm{C}$ and $90 \%$ relative humidity for 1 day. After removal from the moulds the pastes were stored in water for 1, 3, 7, 28 or 90 days, at which times they were tested for compressive strength. The fragments were then immersed in alcohol to detain hydration and vacuum dried at $30{ }^{\circ} \mathrm{C}$ for further analysis.

\subsection{Test methods}

Clinker fineness was determined by negative pressure sieving as per Chinese standard GB/T1345-1991. The unsieved residue was held within $0.5-3 \mathrm{wt} \%$. Compressive strength was determined on a $50-\mathrm{kN}$ MTS CMT5504 test frame (China). XRD patterns were recorded on a Bruker D8 Advance diffractometer (Germany) fitted with a $\mathrm{Cu} \mathrm{K} \alpha \mathrm{X}$-ray tube and operating a $40 \mathrm{kV}$ and $40 \mathrm{~mA}$. Readings were taken between $2 \theta$ angles of 5 to $60^{\circ}$ with a step size 
of $0.02^{\circ}$ and a scan speed of 0.2 s. SEM analyses were conducted on a FEI QUANTA FEG (USA) scanning electron microscope operating at $20 \mathrm{kV}$ and $20 \mathrm{~mA}$. The EDS findings were obtained on an Oxford Instruments INCA energy X-MAX-50X analyser (UK). A TAM Air eight-channel, thermometric isothermal conduction calorimeter was used to determine heat of hydration and heat flow. DSC data were logged with a TGA/DSC1/1600HT analyser from ambient temperature to $650{ }^{\circ} \mathrm{C}$, ramping at a rate of $10^{\circ} \mathrm{C} / \mathrm{min}$.

\section{RESULTS AND DISCUSSION}

\subsection{Variation in phase composition}

The XRD patterns for anhydrous phosphoaluminate cement with varying $\mathrm{Fe}_{2} \mathrm{O}_{3}$ contents sintered at $1380{ }^{\circ} \mathrm{C}$ and for two reference specimens without the oxide sintered at 1380 and $1560{ }^{\circ} \mathrm{C}$ are reproduced in Figure 1. As the figure shows, the main phases identified in specimen $\mathrm{A}\left(0 \% \mathrm{Fe}_{2} \mathrm{O}_{3}\right)$ included modified $\mathrm{CA}_{1-\mathrm{Y}}\left(\mathrm{P}_{\mathrm{Y}}\right), \mathrm{C}_{12} \mathrm{~A}_{7}$ and $\mathrm{CP}_{1-\mathrm{z}}\left(\mathrm{A}_{\mathrm{z}}\right)$, while only traces of LHss were detected. In contrast, large quantities of LHss (lines at $23.751^{\circ}, 33.858^{\circ}$, $41.756^{\circ}$ ) were present in specimen $\mathrm{G}$ (likewise with $0 \% \mathrm{Fe}_{2} \mathrm{O}_{3}$ ), whose diffractogram showed no signals for $\mathrm{CA}_{1-\mathrm{Y}}\left(\mathrm{P}_{\mathrm{Y}}\right), \mathrm{C}_{12} \mathrm{~A}_{7}$ or $\mathrm{CP}_{1-\mathrm{z}}\left(\mathrm{A}_{\mathrm{z}}\right)$. In other words, LHss was observed to form at high temperatures even without $\mathrm{Fe}_{2} \mathrm{O}_{3}$.

In specimens $\mathrm{B}$ to $\mathrm{E}$, with $\mathrm{Fe}_{2} \mathrm{O}_{3}$ ranging from 10 to $13 \%$, the main phases were $\mathrm{CA}_{1-\mathrm{Y}}\left(\mathrm{P}_{\mathrm{Y}}\right)$ and $\mathrm{CP}_{1-\mathrm{z}}\left(\mathrm{A}_{\mathrm{z}}\right)$. In these patterns, the LHss signal was more intense than on the pattern for specimen $A$, while the line for $\mathrm{C}_{12} \mathrm{~A}_{7}$ disappeared and a new phase, $\mathrm{C}_{\mathrm{A}} \mathrm{AF}$, formed. According to these findings, $\mathrm{Fe}_{2} \mathrm{O}_{3}$ would favour the reaction between $\mathrm{C}_{12} \mathrm{~A}_{7}$ and phosphorus

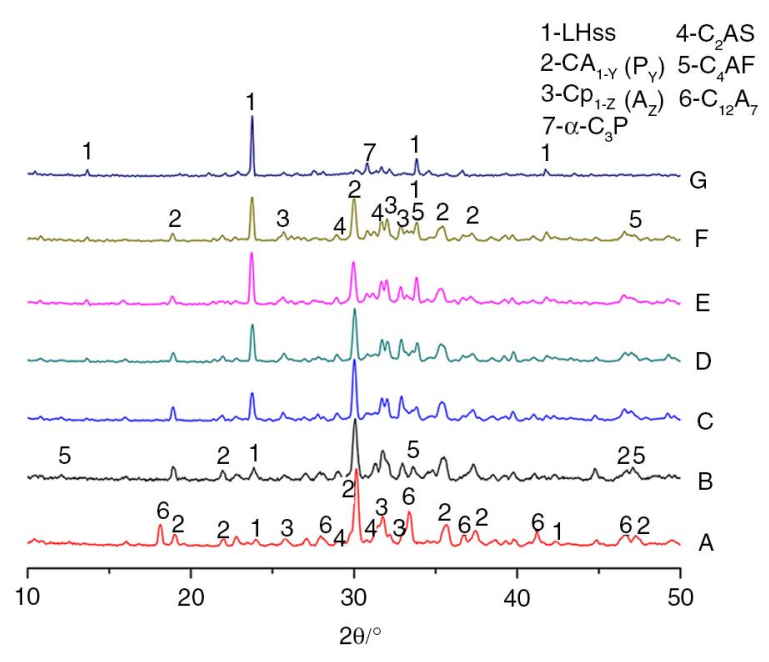

FIGURE 1. XRD patterns for anhydrous phosphoaluminate cement containing $0,10,11,12,13$ or $15 \% \mathrm{Fe}_{2} \mathrm{O}_{3}$. oxide, yielding mineral LHss at the lower temperature, while $\mathrm{C}_{4} \mathrm{AF}$ would be the product of the reaction between $\mathrm{Fe}_{2} \mathrm{O}_{3}$ and $\mathrm{C}_{12} \mathrm{~A}_{7}$. The intensity of the LHss diffraction line rose while the signals for $\mathrm{C}_{4} \mathrm{AF}$, $\mathrm{CA}_{1-\mathrm{Y}}\left(\mathrm{P}_{\mathrm{Y}}\right)$ and $\mathrm{CP}_{1-\mathrm{z}}\left(\mathrm{A}_{\mathrm{z}}\right)$ weakened with rising $\mathrm{Fe}_{2} \mathrm{O}_{3}$ content. Therefore, like high temperature, moderate percentages of $\mathrm{Fe}_{2} \mathrm{O}_{3}$ favoured LHss formation from $\mathrm{CA}_{1-\mathrm{Y}}\left(\mathrm{P}_{\mathrm{Y}}\right), \mathrm{CP}_{1-\mathrm{z}}\left(\mathrm{A}_{\mathrm{z}}\right)$ and $\mathrm{C}_{4} \mathrm{AF}$.

When the $\mathrm{Fe}_{2} \mathrm{O}_{3}$ dose was increased to $15 \%$, however, as in specimen F, LHss formation declined. The possible explanation lies in $\mathrm{Fe}_{2} \mathrm{O}_{3}$ 's role as intermediate network oxide in partially molten clinker. At low percentages, it would act as a network modifier oxide, lowering the viscosity of the molten phase and favouring LHss formation. At an overly high content, however, $\mathrm{Fe}_{2} \mathrm{O}_{3}$ would act as a network former, hindering ion migration and inhibiting crystal precipitation (19).

The SEM and EDS element maps for specimen E $\left(13 \% \mathrm{Fe}_{2} \mathrm{O}_{3}\right)$, taken as an example of mineral morphology and $\mathrm{Fe}_{2} \mathrm{O}_{3}$ distribution in the cement, are shown in Figure 2. Al, P and Ca overlapped in the regularly shaped $\alpha$ particles, which consequently consisted of calcium phosphoaluminate or modified monocalcium aluminate. The $\mathrm{P} / \mathrm{Ca}$ overlap in the $\beta$ particles was evidence that they consisted of calcium phosphate. The $\mathrm{Ca}$ content was observed to be higher in calcium phosphate than in calcium phosphoaluminate and modified monocalcium aluminate. Si was distributed evenly across all the minerals.

As Figure 2(f) shows, the iron phase was found in interstitial positions between the crystals, where it acted as a mineraliser during clinker sintering, confirming the XRD findings discussed above. The EDS-determined ferrite composition at seven points on the iron phase $(20,21)$ are given in Table 1 . The respective chemical formulas, calculated from the EDS data, are listed in the last column of the table. These findings revealed substantial variation in ferrite composition, which in this phosphoaluminate cement comprised a series of solid solutions comparable to the solutions in portland and calcium aluminate cements (22-24).

\subsection{Compressive strength}

The compressive strength values of the pastes at different ages are listed in Table 2. Figure 1 showed that the main minerals present in A were modified monocalcium aluminate $\left(\mathrm{CA}_{1-\mathrm{Y}}\left(\mathrm{P}_{\mathrm{Y}}\right)\right)$ and dodecacalcium hepta-aluminate $\left(\mathrm{C}_{12} \mathrm{~A}_{7}\right)$. The former would clearly afford the paste early age strength, which rose to day 7 and remained constant thereafter. In the XRD pattern for paste $G$, which unlike the other cements was sintered at $1560{ }^{\circ} \mathrm{C}$, the diffraction line for LHss predominated over all the other minerals present. 
(a) SEM micrograph of clinker

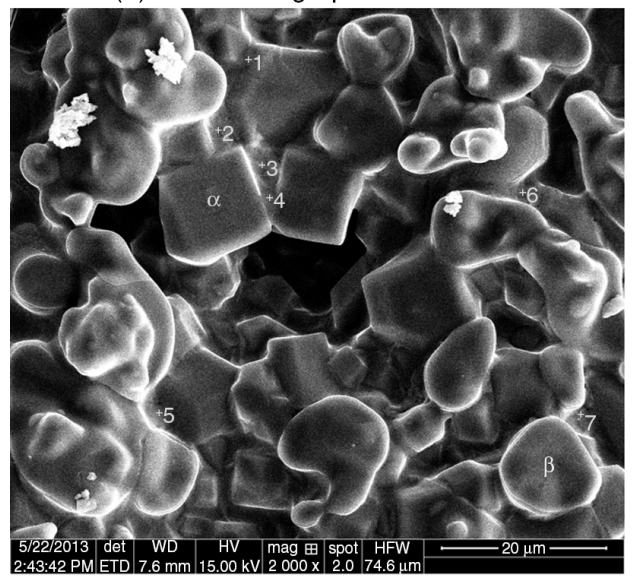

(c) $\mathrm{P}$ distribution (EDS mapping)

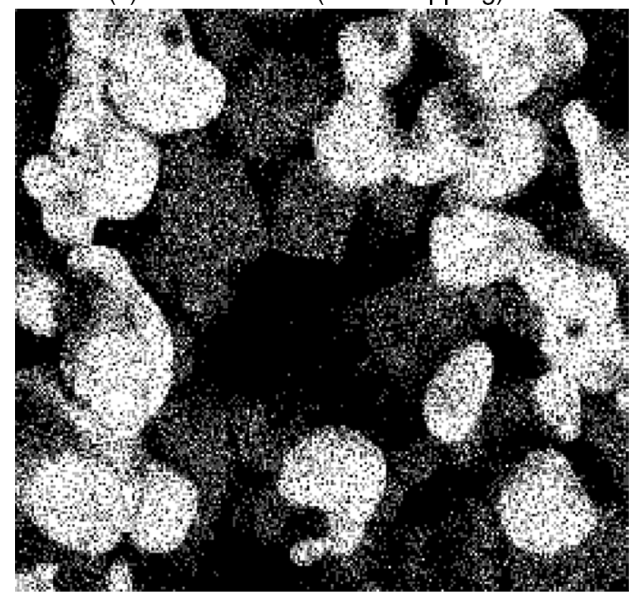

(e) Si distribution (EDS mapping)

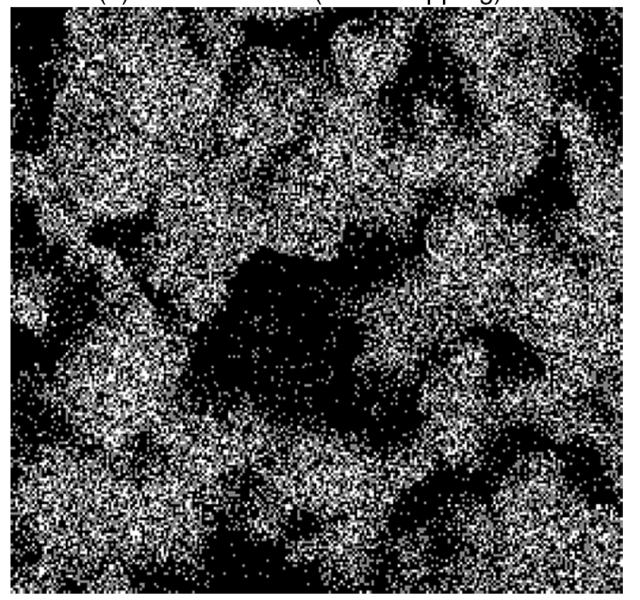

(b) Al distribution (EDS mapping)

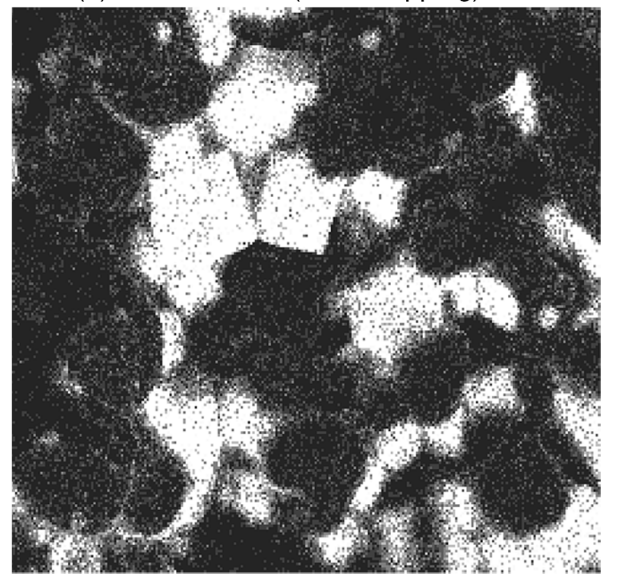

(d) Ca distribution (EDS mapping)

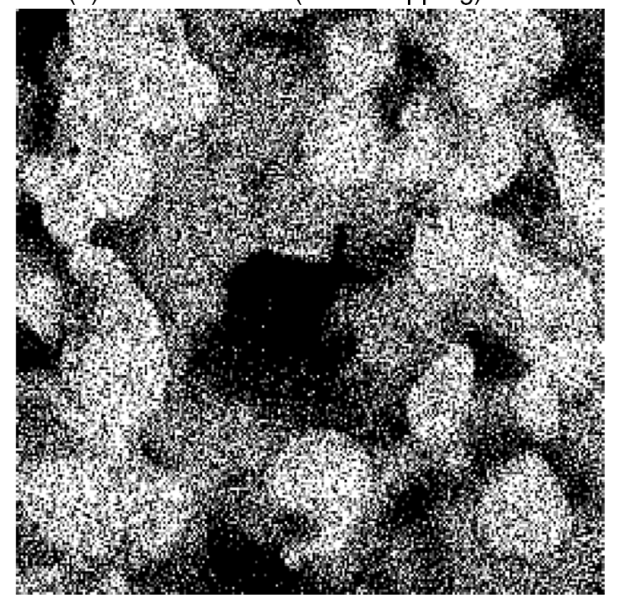

(f) Fe distribution (EDS mapping)

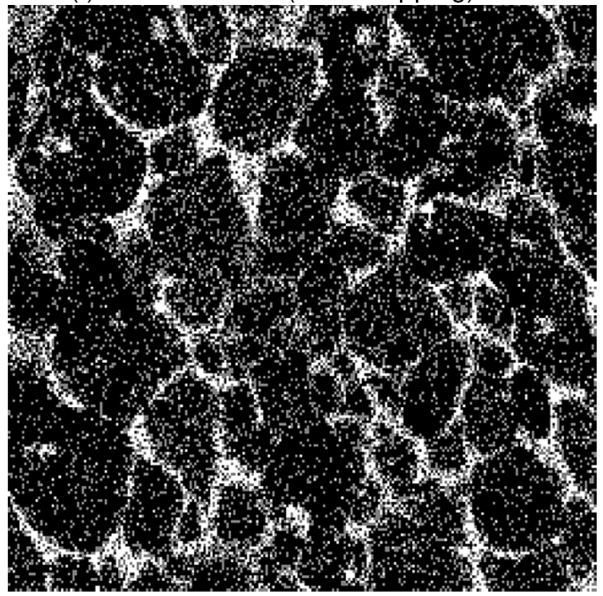

FIGURE 2. SEM analysis of specimen E.

The data in Table 2 show that while early age strength was much lower in paste $G$ than in paste A, the 28- and 90-day strength values were higher in the former. Paste $\mathrm{C}$, which had higher early age strength than specimen E, according to Figure 1, contained more $\mathrm{CA}_{1-\mathrm{Y}}\left(\mathrm{P}_{\mathrm{Y}}\right)$ and less LHss than specimen $\mathrm{E}$. The higher rate of strength development in
E between 3 and 90 days would indicate that LHss enhances cement strength at later ages. Early age compressive strength declined significantly with rising percentages of $\mathrm{Fe}_{2} \mathrm{O}_{3}$, while later age strength rose visibly. The conclusion that may be drawn is that $\mathrm{Fe}_{2} \mathrm{O}_{3}$ favoured the conversion of $\mathrm{CA}_{1-\mathrm{Y}}\left(\mathrm{P}_{\mathrm{Y}}\right)$ to LHss, thereby raising later age compressive strength. 
TABLE 1. EDS analysis of ferrite in phosphoaluminate cement

\begin{tabular}{|c|c|c|c|c|c|c|}
\hline \multirow[b]{2}{*}{ Point $^{\mathrm{a}}$} & \multicolumn{5}{|c|}{ Element (atomic percentage) } & \multirow[b]{2}{*}{ Chemical formula $^{b}$} \\
\hline & $\mathrm{Ca}$ & Al & $\mathrm{Fe}$ & $\mathbf{P}$ & $\mathbf{S i}$ & \\
\hline 1 & 31.34 & 2.26 & 14.96 & 0.29 & 0.19 & $\mathrm{C}_{1.77} \mathrm{~F}_{0.85}(\mathrm{Al}(\mathrm{Si}, \mathrm{P}))_{0.15}$ \\
\hline 2 & 23.56 & 1.82 & 23.81 & 0.19 & 0.02 & $\mathrm{C}_{1.82} \mathrm{~F}_{0.92}(\mathrm{Al}(\mathrm{Si}, \mathrm{P}))_{0.08}$ \\
\hline 3 & 25.19 & 1.33 & 23.04 & 0.00 & 0.07 & $\mathrm{C}_{2.05} \mathrm{~F}_{0.94}(\mathrm{Al}(\mathrm{Si}, \mathrm{P}))_{0.06}$ \\
\hline 4 & 38.29 & 3.76 & 5.70 & 0.58 & 0.20 & $\mathrm{C}_{7.33} \mathrm{~F}_{0.55}(\mathrm{Al}(\mathrm{Si}, \mathrm{P}))_{0.45}$ \\
\hline 5 & 31.32 & 2.69 & 14.49 & 0.36 & 0.12 & $\mathrm{C}_{3.52} \mathrm{~F}_{0.81}(\mathrm{Al}(\mathrm{Si}, \mathrm{P}))_{0.19}$ \\
\hline 6 & 33.81 & 2.27 & 12.76 & 0.19 & 0.17 & $\mathrm{C}_{4.34} \mathrm{~F}_{0.82}(\mathrm{Al}(\mathrm{Si}, \mathrm{P}))_{0.18}$ \\
\hline 7 & 31.11 & 4.40 & 11.49 & 0.97 & 0.13 & $\mathrm{C}_{2.75} \mathrm{~F}_{0.67}(\mathrm{Al}(\mathrm{Si}, \mathrm{P}))_{0.33}$ \\
\hline
\end{tabular}

a: on Figure 2(a).

b: $\mathrm{C}=\mathrm{CaO} ; \mathrm{F}=\mathrm{Fe}_{2} \mathrm{O}_{3} ; \mathrm{Al}=\mathrm{Al}_{2} \mathrm{O}_{3} ; \mathrm{Si}=\mathrm{SiO}_{2} ; \mathrm{P}=\mathrm{P}_{2} \mathrm{O}_{5}$.
This reasoning is consistent with the XRD findings. Hence, the compressive strength of phosphoaluminate cement paste may be modified by controlling the $\mathrm{Fe}_{2} \mathrm{O}_{3}$ dosage used.

\subsection{Analysis of hydration products}

The XRD patterns for the 1-, 3-, 7-, 28- and 90-day A, C and E cement pastes are reproduced in Figure 3. The signal for $\mathrm{CA}_{1-\mathrm{Y}}\left(\mathrm{P}_{\mathrm{Y}}\right)$ was weak after just 1 day, an indication that it was largely consumed. In contrast, relatively intense diffraction lines for this mineral on the patterns for 3-day paste $\mathrm{A}$ showed that the addition of $\mathrm{Fe}_{2} \mathrm{O}_{3}$ favoured $\mathrm{CA}_{1-\mathrm{Y}}\left(\mathrm{P}_{\mathrm{Y}}\right)$ hydration. As $\mathrm{CA}_{1-\mathrm{Y}}\left(\mathrm{P}_{\mathrm{Y}}\right)$ hydrated, the

TABLE 2. Compressive strength of 1-, 3-, 7-, 28-, and 90-day cement pastes

\begin{tabular}{lcccccccccc}
\hline & \multicolumn{2}{c}{ 1d } & \multicolumn{2}{c}{ 3d } & \multicolumn{2}{c}{ 7d } & \multicolumn{2}{c}{ 28d } & \multicolumn{2}{c}{ 90d } \\
\cline { 2 - 10 } Specimen & Mean & Error & Mean & Error & Mean & Error & Mean & Error & Mean & Error \\
\hline A & 46.84 & 0.95 & 58.92 & 2.14 & 71.12 & 0.92 & 71.32 & 2.54 & 69.23 & 2.78 \\
C & 39.54 & 1.64 & 55.02 & 1.81 & 79.26 & 2.51 & 89.91 & 1.24 & 109.11 & 2.20 \\
E & 18.23 & 1.04 & 27.55 & 1.44 & 33.75 & 1.60 & 55.63 & 1.66 & 81.22 & 2.38 \\
G & 16.01 & 1.06 & 43.33 & 1.80 & 66.28 & 1.94 & 86.63 & 2.31 & 103.80 & 2.28 \\
\hline
\end{tabular}

(a)

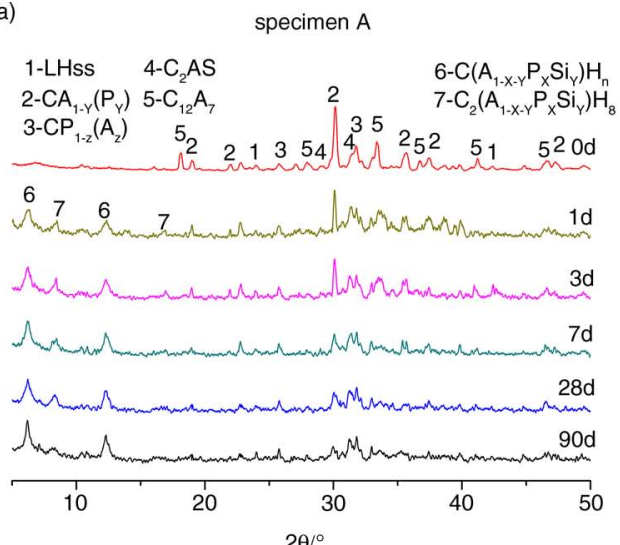

(b)

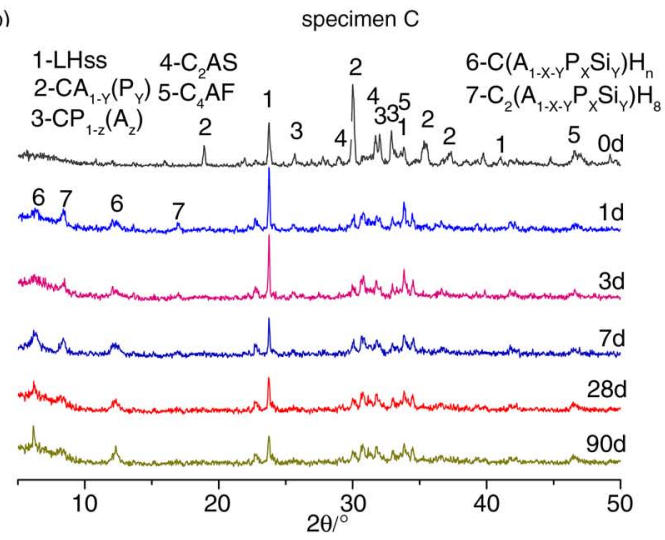

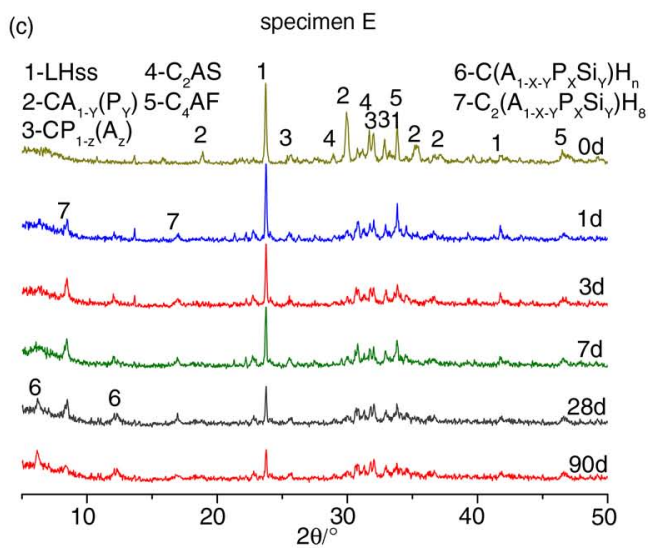

Figure 3. 1-, 3-, 7-, 28- and 90-day XRD patterns for specimens A, C and E. 


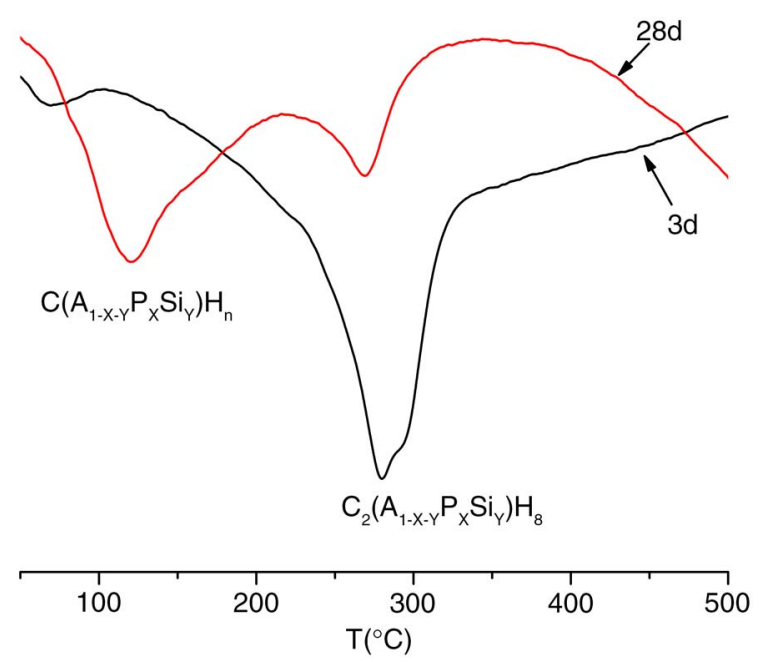

FIgURE 4. 3- and 28-day DSC diagrams for specimen C.

intensity of the signals at $2 \theta$ angles of $8.460^{\circ}$ and $16.941^{\circ}$ for $\mathrm{C}_{2}\left(\mathrm{~A}_{1-\mathrm{X}-\mathrm{Y}} \mathrm{P}_{\mathrm{X}} \mathrm{Si}_{\mathrm{Y}}\right) \mathrm{H}_{8}$ grew. These values were shifted from the $8.256^{\circ}$ and $16.525^{\circ}$ recorded for $\mathrm{C}_{2} \mathrm{AH}_{8}$ due to the replacement of $\mathrm{Al}$ by $\mathrm{P}$ and $\mathrm{Si}$. The line for $\mathrm{C}_{2}\left(\mathrm{~A}_{1-\mathrm{X}-\mathrm{Y}} \mathrm{P}_{\mathrm{X}} \mathrm{Si}_{\mathrm{Y}}\right) \mathrm{H}_{8}$ practically disappeared in the 28-day pattern for paste $\mathrm{C}$, however, with its conversion into $\mathrm{C}\left(\mathrm{A}_{1-\mathrm{X}-\mathrm{Y}} \mathrm{P}_{\mathrm{X}} \mathrm{Si}_{\mathrm{Y}}\right) \mathrm{H}_{\mathrm{n}}$ at later ages (25). These findings were confirmed by the DSC analysis of paste $\mathrm{C}$ shown in Figure 4.

The intensity of the signals generated by $\mathrm{C}\left(\mathrm{A}_{1-\mathrm{X}-\mathrm{Y}} \mathrm{P}_{\mathrm{X}} \mathrm{Si}_{\mathrm{Y}}\right) \mathrm{H}_{\mathrm{n}}\left(6.201^{\circ}, 12.299^{\circ}\right)$ rose with curing age. Since $\mathrm{CA}_{1-\mathrm{Y}}\left(\mathrm{P}_{\mathrm{Y}}\right)$ was almost entirely consumed in the first day, the hydration product detected, $\mathrm{C}\left(\mathrm{A}_{1-\mathrm{X}-\mathrm{Y}} \mathrm{P}_{\mathrm{X}} \mathrm{Si}_{\mathrm{Y}}\right) \mathrm{H}_{\mathrm{n}}$, must have been the result of LHss hydration. Unlike $\mathrm{CAH}_{10}$ $\left(6.219^{\circ}, 12.352^{\circ}\right)$, which is unstable in high alumina cement, $\mathrm{C}\left(\mathrm{A}_{1-\mathrm{X}} \mathrm{P}_{\mathrm{X}} \mathrm{Si}_{\mathrm{Y}}\right) \mathrm{H}_{\mathrm{n}}$ was stable due to the replacement of Al by P and Si (25). The diffraction lines associated with LHss declined in intensity after 90 days, when more $\mathrm{C}\left(\mathrm{A}_{1-\mathrm{X}} \mathrm{P}_{\mathrm{X}} \mathrm{Si}_{\mathrm{Y}}\right) \mathrm{H}_{\mathrm{n}}$ was found in the system. As the solid solution of $\mathrm{P}$ and $\mathrm{Si}$ in LHss prevented $\mathrm{C}_{2} \mathrm{AH}_{8}$ and $\mathrm{CAH}_{10}$ from converting to $\mathrm{C}_{3} \mathrm{AH}_{6}$, compressive strength rose continuously in these specimens. Figure 5 shows the 1-day SEM micrograph and EDS analysis for specimen $\mathrm{C}$, in which flaky hydration products were observed. EDS identified points
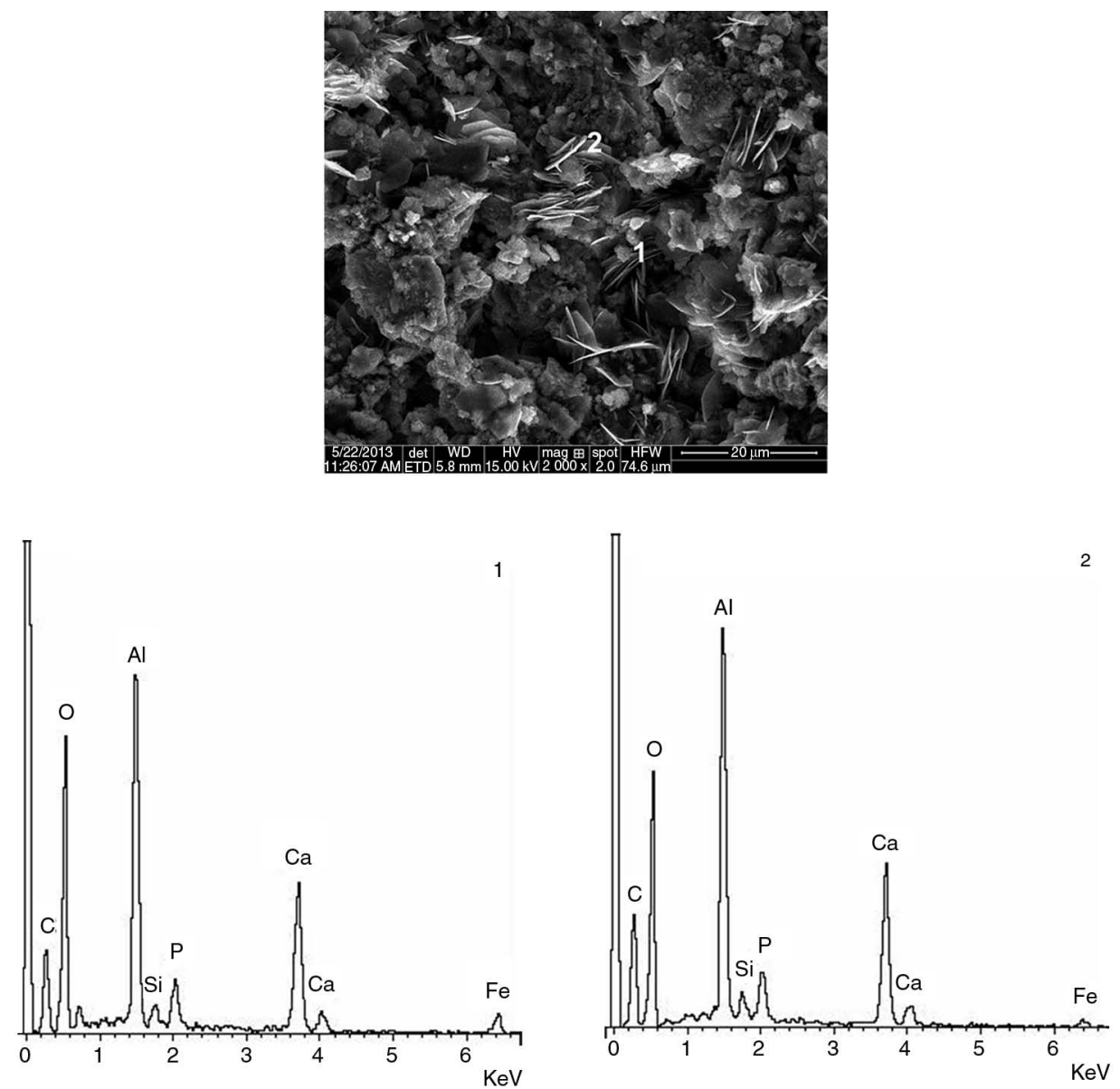

FIgURE 5. 1-day SEM-EDS analysis for specimen C. 


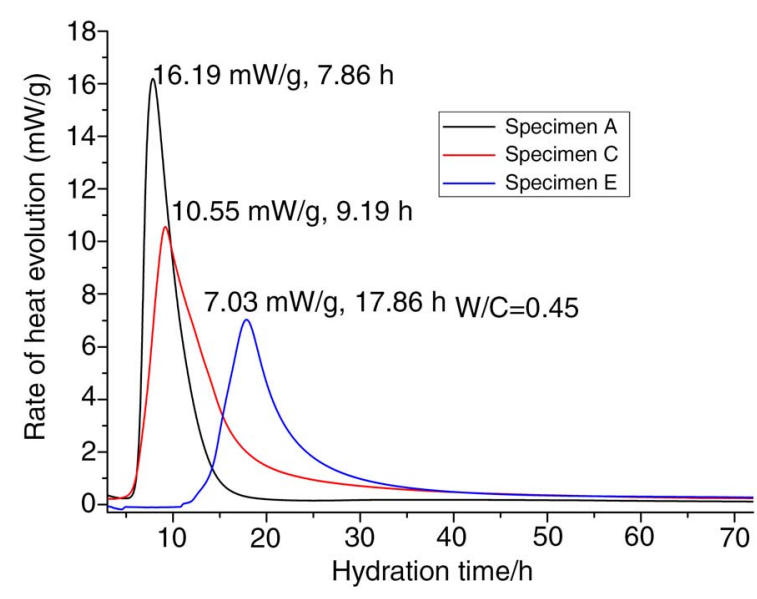

Figure 6. Heat flow curves for specimens A, C and E.

1 and 2 as $\mathrm{C}_{2}\left(\mathrm{~A}_{1-\mathrm{X}-\mathrm{Y}} \mathrm{P}_{\mathrm{X}} \mathrm{Si}_{\mathrm{Y}}\right) \mathrm{H}_{8}$, a finding consistent with the XRD results.

\subsection{Heat of hydration}

The heat flow curves plotted are shown in Figure 6. The figure shows that hydration peaked in paste $\mathrm{A}$ at $16.19 \mathrm{~mW} / \mathrm{g}$ after $7.86 \mathrm{~h}$ and in paste $\mathrm{C}$ at $10.55 \mathrm{~mW} / \mathrm{g}$ after $9.19 \mathrm{~h}$. Both peaks were associated with swift $\mathrm{CA}_{1-\mathrm{Y}}\left(\mathrm{P}_{\mathrm{Y}}\right)$ hydration. The paste $\mathrm{E}$ hydration peak was recorded at $7.03 \mathrm{~mW} / \mathrm{g}$ after 17.86 h. Unlike paste C, paste E exhibited no significant heat peak in the first 10 hours. The reason was that the $\mathrm{Fe}_{2} \mathrm{O}_{3}$ added had already induced $\mathrm{CA}_{1-\mathrm{Y}}\left(\mathrm{P}_{\mathrm{Y}}\right)$ conversion to LHss.

\section{CONCLUSIONS}

A certain amount of iron oxide acts as a mineraliser, favouring the conversion of $\mathrm{CA}_{1-\mathrm{Y}}\left(\mathrm{P}_{\mathrm{Y}}\right)$ to LHss at lower than the usual temperature. The ferrite occupies primarily interstitial positions. The main hydration products in iron oxide-rich phosphoaluminate cement are $\mathrm{C}_{2}\left(\mathrm{~A}_{1-\mathrm{X}-\mathrm{Y}} \mathrm{P}_{\mathrm{X}} \mathrm{Si}_{\mathrm{Y}}\right) \mathrm{H}_{8}$, and $\mathrm{C}\left(\mathrm{A}_{1-\mathrm{X}-\mathrm{Y}} \mathrm{P}_{\mathrm{X}} \mathrm{Si}_{\mathrm{Y}}\right) \mathrm{H}_{\mathrm{n}}$. While the former ultimately converts to the latter, this conversion entails no decline in strength. The inclusion of $\mathrm{P}$ and $\mathrm{Si}$ in solid solution with $\mathrm{C}\left(\mathrm{A}_{1-\mathrm{X}-\mathrm{Y}} \mathrm{P}_{\mathrm{X}} \mathrm{Si}_{\mathrm{Y}}\right) \mathrm{H}_{\mathrm{n}}$ renders the system fairly stable. As LHss hydrates at later ages, strength grows continuously in the hardened cement paste. While adding $\mathrm{Fe}_{2} \mathrm{O}_{3}$ lowers the early age strength of the hardened paste, it enhances the later age strength. The modification of the $\mathrm{Fe}_{2} \mathrm{O}_{3}$ dosage can be used to control the composition of phosphoaluminate cement to produce a material compliant with different mechanical strength requirements. Hydration is deeply affected by $\mathrm{Fe}_{2} \mathrm{O}_{3}$ : when the oxide was added at a rate of $11 \%$, heat flow peaked at $10.55 \mathrm{~mW} / \mathrm{g}$ after $9.19 \mathrm{~h}$, while at $13 \%$ the peak declined to just $7.03 \mathrm{~mW} / \mathrm{g}$.

\section{ACKNOWLEDGEMENT}

This study was funded by the Natural Science Foundation of China (No.51272091 and No.51302104). Meanwhile, this work was supported by Program for Scientific Research Innovation Team in Colleges and Universities of Shandong Province.

\section{REFERENCES}

1. Bradbury, C.; Callaway, P.M.; Double, D.D. (1976) The conversion of high alumina cement/concrete. Mater. Sci. Eng. 1 [23], 43-53. http://dx.doi.org/10.1016/0025-5416(76) 90085-9

2. Midgley, H.G.; Ryder, J.F. (1977) The relationship between mineral composition and strength development of high alumina cement. Cem. Concr. Res. 7, 669-672. http:// dx.doi.org/10.1016/0008-8846(77)90049-7.

3. Mangabhai, R.J.; Glasser, F.P. (2001). Calcium Aluminate Cements 2001: Proceedings of the International Conference on Calcium Aluminate Cements (CAC) Held at HeriotWatt University Edinburgh, Scotland, UK, 16-19 July 2001, IOM Communications.

4. Kirca, O.; Yaman, I.O.; Tokyay, M. (2013) Compressive strength development of calcium aluminate cementGGBFS blends, Cem. Concr. Comp. 35 [1], 163-170. http:// dx.doi.org/10.1016/j.cemconcomp.2012.08.016.

5. Neven, U.; Anamarija, R. (2013) Styrene-butadiene latex modified calcium aluminate cement mortar. Cem. Concr. Comp. 41, 16-23. http://dx.doi.org/10.1016/j.cemconcomp. 2013.04.012.

6. Luz, A.P.; Pandolfelli, V.C. (2012) $\mathrm{CaCO}_{3}$ addition effect on the hydration and mechanical strength evolution of calcium aluminate cement for endodontic applications. Ceram. Int. 38, 1417-1425. http://dx.doi.org/10.1016/j.ceramint.2011.09.021.

7. Jiashan, H. (2004) Phosphorus-aluminate binding material system. C.N. patent 1498870A, issued May 26, 2004.

8. Shiqun, L.; Guohui, Z.; Ning, Z.; Biao, L.; Wui, C.; Jiashan, H. (1998) Study on hydraulic activity of aluminum-rich area in $\mathrm{CaO}-\mathrm{Al}_{2} \mathrm{O}_{3}-\mathrm{P}_{2} \mathrm{O}_{5}$ system. J. Chin. Ceram. Soc. 26 [2], 142-148. http://dx.doi.org/10.3321/j. issn:0454-5648.1998.02.003.

9. Shiqun, L.; Jiashan, H.; Biao, L.; Guohui, Z.; Wei, C.; Qi, W.; Ning, Z. (1999) Fundamental study on aluminophosphate cement. Cem. Concr. Res. 29, 1549-1554. http:// dx.doi.org/10.1016/s0008-8846(99)00111-8.

10. Jia, L.; Shiqun, L.; Jiashan, H.; Biao, L.; Qi, W. (2001) Study on the aluminophosphate glass-rich cement. Cem. Concr. Res. 31, 949-952. http://dx.doi.org/10.1016/S0008-8846 (01)00503-8.

11. Shuguang, H. (2010) Special Cements. Wuhan University of Technology Press, Wuhan.

12. Shiqun, L.; Zhaohua, Y.; Wei, W.; Fengyan, Z.; Biao, L.; Jiashan, H. (2007) Fundamental study on the chemical stability of hardened pastes of phosphoaluminate cement. Mater. Res. Innov. 11 [2], 78-82. http://dx.doi.org/ $10.1179 / 143307507 \times 196590$

13. Guonian, W. (2002) $\mathrm{S}^{6+}, \mathrm{Fe}^{3+}, \mathrm{Mg}^{2+}, \mathrm{Ti}^{4+}$ on the phase formation of $\mathrm{CaO}-\mathrm{SiO}_{2}-\mathrm{Al}_{2} \mathrm{O}_{3}-\mathrm{P}_{2} \mathrm{O}_{5}$ system. Master's degree thesis, Shandong Institute of Building Materials, Jinan, China.

14. Tenorio, J.A.S.; Pereira, S.S.R.; Ferreira, A.V.; Romano Espinosa, D.C.; da Silva Araújo, F.G. (2004) CCT diagrams of tricalcium silicate Part I. Influence of the $\mathrm{Fe}_{2} \mathrm{O}_{3}$ content. Materials Research Bulletin. 3 [40], 433-438. http://dx.doi. org/10.1016/j.materresbull.2004.12.005.

15. Dietmar, S.; Sophie, N.D.; Gabriele, R.S. (2008) Influence of combined doping of tricalcium silicate with $\mathrm{MgO}$, $\mathrm{Al}_{2} \mathrm{O}_{3}$ and $\mathrm{Fe}_{2} \mathrm{O}_{3}$ : synthesis, grindability, X-ray diffraction and ${ }^{29} \mathrm{Si}$ NMR. Mater. Struct. 41, 1729-1740 http://dx.doi. org/10.1617/s11527-008-9360-3.

16. Xiaocun, L.; Yanjun, L. (2005) Effect of $\mathrm{MgO}$ on the composition and properties of alite-suphoaluminated cement. 
Cem. Concr. Res. 35, 1685-1687. http://dx.doi.org/10.1016/j. cemconres.2004.08.008

17. Lingchao, L.; Jun, C.; Yeqing, S.; Xin, C.; Hanxing, L.; Runzhang, Y.(2005) Synthesis and mechanical performance of alite-calcium barium sulphoalumiante cement. J. Chin Ceram. Soc. 33 [7], 902-906. http://dx.doi.org/10.3321/j. issn:0454-5648.2005.07.021.

18. Yong, G.; Junan, D.; Muzhen, S.; Yanmou. W. (1988) A study on formation mechanism of ferrite phase in ferroaluminate cement. J. Chin. Ceram. Soc. 16 [6], 481-487.

19. Gollop, R.S.; Taylor, H.F.W. (1994) Microstructural and microanalytical studies of sulfate attack. II. Sulfateresisting Portland cement: Ferrite composition and hydration chemistry. Cem. Concr. Res. 24 [7], 1347-1358. http:// dx.doi.org/10.1016/0008-8846(94)90120-1.

20. Miler, M. Mirtič, B. (2013) Accuracy and precision of EDS analysis for identification of metal-bearing minerals in polished and rough particle samples. Geologija. 56 [1], 5-18. http://dx.doi.org/10.5474/geologija.2013.001.

21. Michael, C.M.; Peter, A.; Peter, T. (2013) Quantitative evaluation of mineral grains using automated SEM-EDS analysis and its application potential in optically stimulated luminescence dating. Radiat. Meas. 58, 1-11. http://dx.doi. org/10.1016/j.radmeas.2013.07.004.

22. Yanwei, Z.; Nanru, Y. (1991) A comparative study of the ferritephase in high-iron cement with the pure $\mathrm{C}_{2} \mathrm{~A}_{\mathrm{x}} \mathrm{F}_{1-\mathrm{x}}$ by Mössbauer spectroscopy. Cem. Concr. Res. 21, 31-37. http://dx.doi.org/10.1016/0008-8846(91)90028-G.

23. Harchand, K.S.; Chandra. K. (1983) A study of $\mathrm{CaO}$ $\left(\mathrm{Fe}_{2} \mathrm{O}_{3}\right)_{1}-\mathrm{x}\left(\mathrm{Al}_{2} \mathrm{O}_{3}\right) \mathrm{x}$ system. Cem. Concr. Res. 13, 465-469. http://dx.doi.org/10.1016/0008-8846(83)90003-0.

24. Harch, K.S.; Vishwamitter Chandra, K. (1984) A study of iron phase and its hydration behaviour in high alumina cement. Cem. Concr. Res. 14, 19-24. http://dx.doi.org/ 10.1016/0008-8846(84)90075-9.

25. Fawei, Z. (2007) The hydration performance and mechanism of phosphoaluminate cement, magnesium phosphate cement and compound phosphoaluminate-magnesium phosphate cement. Master's degree thesis. Jinan University, Jinan, China. 